Check for updates

Cite this: RSC Adv., 2019, 9, 28916

\title{
Natural rubber latex foam with particulate fillers for carbon dioxide adsorption and regeneration
}

\author{
Krittaya Panploo, ${ }^{a}$ Benjapon Chalermsinsuwan (DD ${ }^{\text {ab }}$ and Sirilux Poompradub (D) *abc
}

To reduce the carbon dioxide $\left(\mathrm{CO}_{2}\right)$ concentration in the atmosphere, natural rubber (NR) was developed as a rubber foam for $\mathrm{CO}_{2}$ adsorption. Although the $\mathrm{CO}_{2}$ adsorption capacity of the NR latex foam produced by mixing with a cake mixer (CM) was higher than that produced with an overhead stirrer (OS), both capacity values were still low. To improve the $\mathrm{CO}_{2}$ adsorption capacity, the use of unmodified and (3-aminopropyl) triethoxysilane-modified silica particles as fillers in the CM rubber foam matrix was examined. The highest $\mathrm{CO}_{2}$ adsorption capacity, from a mixed gas flow rate of $100 \mathrm{~mL} \mathrm{~min}^{-1}$ at ambient temperature and pressure, was obtained with the $\mathrm{CM}$ foam filled with 5 parts by weight per hundred parts of rubber filled with modified silica particles $\left(4.08 \mathrm{mg} \mathrm{g}^{-1}\right.$ ). The $\mathrm{CO}_{2}$ adsorption capacity of this foam was approximately 1.11 - and 2.87fold higher than that of the CM foam filled with unmodified silica particles $\left(3.69 \mathrm{mg} \mathrm{g}^{-1}\right.$ ) and unfilled CM rubber $\left(1.42 \mathrm{mg} \mathrm{g}^{-1}\right)$, respectively. Morphological analysis supported that the cell size and number of pores per cell of the NR latex foam, which were higher in the CM foams than the OS foams, were important factors for evaluating $\mathrm{CO}_{2}$ adsorption. In addition to physisorption between $\mathrm{CM}$ and $\mathrm{CO}_{2}$, chemisorption between the modified silica particles and $\mathrm{CO}_{2}$ increased the $\mathrm{CO}_{2}$ adsorption capacity.

Received 2nd August 2019

Accepted 6th September 2019

DOI: $10.1039 /$ c9ra06000f

rsc.li/rsc-advances has already been used for various applications, such as gas storage, gas separation, catalysis, sensing, clean energy, $\mathrm{CO}_{2}$ capture and so on. ${ }^{21-25}$ However, to make MOPs eco-friendlier, the development of natural polymers is an alternative choice for $\mathrm{CO}_{2}$ capture.

Natural rubber (NR) is a natural commodity that has tremendous economic and strategic importance due to its unique characteristics such as a high strength, flexibility, and elasticity. ${ }^{26}$ In addition, the NR latex foam can be used as a good absorbent material, including as a chemical, ${ }^{27}$ sound $^{28}$ and oil $^{29,30}$ absorbent. However, in general, rubber products cannot be used at high temperatures due to their low thermal properties. Silica is a reinforcing filler that is widely used in rubber products, ${ }^{31,32}$ since it can improve not only the mechanical but also the thermal properties of rubber products, ${ }^{33}$ and it has been reported to be an important physisorption material for $\mathrm{CO}_{2}$ adsorption. ${ }^{34,35}$ However, the selectivity of $\mathrm{CO}_{2}$ adsorption is low due to the absence of active sites for $\mathrm{CO}_{2}$ capture. Therefore, amine-modified silica was investigated in this study to enhance the adsorption capacity and selectivity for $\mathrm{CO}_{2}$.

Based on the literature studies, NR latex foam is not widely used as a gas adsorbent especially for $\mathrm{CO}_{2}$. This is an importance of this work to present the unique properties of NR for $\mathrm{CO}_{2}$ capture. Accordingly, the originality of this work was the preparation of an alternative material for $\mathrm{CO}_{2}$ capture using NR, because NR can be easily formed into a highly porous foam for trapping gases or liquids. Moreover, NR is an eco-friendly material, compared to conventional solid sorbents, and can be used in various applications at ambient temperature and

\footnotetext{
${ }^{a}$ Department of Chemical Technology, Faculty of Science, Chulalongkorn University, Bangkok 10330, Thailand. E-mail: sirilux.p@chula.ac.th

${ }^{b}$ Center of Excellence on Petrochemical and Materials Technology, Chulalongkorn University, Bangkok 10330, Thailand

${ }^{c}$ Green Materials for Industrial Application Research Unit, Faculty of Science, Chulalongkorn University, Bangkok 10330, Thailand
} 
pressure. $\mathrm{CO}_{2}$ is generally released from diverse sources, such as vehicles, industrial factories, or everyday life of humans. Thus, NR has potential as a solid sorbent in the preparation of $\mathrm{CO}_{2}$ capture materials. In contrast, conventional $\mathrm{CO}_{2}$ capture materials are typically developed as solid states that are suitable only for use at high temperatures. Until now, there have been only a few reports on the use of NR composite materials as potential $\mathrm{CO}_{2}$ adsorbents, ${ }^{36}$ and a mechanism for $\mathrm{CO}_{2}$ adsorption in NR composite materials is still required. Accordingly, the aim of this study was to develop an eco-friendly material for $\mathrm{CO}_{2}$ adsorption at ambient temperature and pressure. The NR latex foam was prepared using either an overhead stirrer or cake mixer, designated as OS or CM, respectively. To improve the $\mathrm{CO}_{2}$ adsorption performance of the CM, it was filled with either unmodified silica (CM-USi) or (3-aminopropyl)triethoxysilane (APTES)-modified silica (CM-MSi). The MSi particles were characterized by Fourier-transform infrared spectroscopy (FTIR) and transmission electron microscopy (TEM). The morphology of the OS, CM, CM-USi, and CM-MSi foams were also studied by scanning electron microscopy (SEM). The effects of the mixed gas $\left(12.88(\mathrm{v} / \mathrm{v}) \mathrm{CO}_{2} /\right.$ nitrogen $\left.\left(\mathrm{N}_{2}\right)\right)$ flow rate on the $\mathrm{CO}_{2}$ adsorption performance of the different NR latex foams with or without the USi or MSi filling were investigated using a stainless-steel reactor at ambient temperature and pressure. Finally, the mechanism for $\mathrm{CO}_{2}$ adsorption by the different NR latex foams is proposed.

\section{Experimental}

\subsection{Materials}

NR latex with a $60 \%$ dry rubber content was used as a raw material. The chemicals for rubber compounding, such as potassium oleate (K-oleate) as a surface active agent, sulfur as a crosslinking agent, zinc diethylthiocarbonate (ZDEC) as an accelerator, zinc 2-mercaptobenzothiazone (ZMBT) as an accelerator, Wingstay L (butylated reaction product of para cresol and dicyclopentadiene) as an antidegradant, diphenyl guanidine (DPG) as an accelerator, zinc oxide (ZnO) as an activator, and sodium silicofluoride (SSF) as an gelling agent, were purchased from the Rubber Research Institute, Bangkok, Thailand and dispersed in water. Tetraethoxysilane (TEOS), used as a silica precursor, and APTES, used as a modifying agent, were from Sigma-Aldrich (Saint Louis, USA). Ammonia solution (28 wt\%), used as a basic catalyst, and absolute ethanol (EtOH), used as a solvent, were purchased from Qrec Chemical Ltd. (Chonburi, Thailand). All chemical reagents were used as received without purification.

\subsection{Preparation of MSi particles}

The MSi particles were prepared by mixing 0.013 mol TEOS, $0.702 \mathrm{~mol}$ EtOH, $0.052 \mathrm{~mol}$ ammonia solution, $0.389 \mathrm{~mol}$ deionized water and $0.007 \mathrm{~mol}$ APTES at ambient temperature and stirring for $24 \mathrm{~h}^{33}$ For preparation of the USi particles, APTES was not added to the solution. The obtained USi or MSi particles were then separated by centrifugation, washed in deionized water, and dried in an oven at $110{ }^{\circ} \mathrm{C}$. The idealized mechanism for silica modification by APTES is shown schematically below.

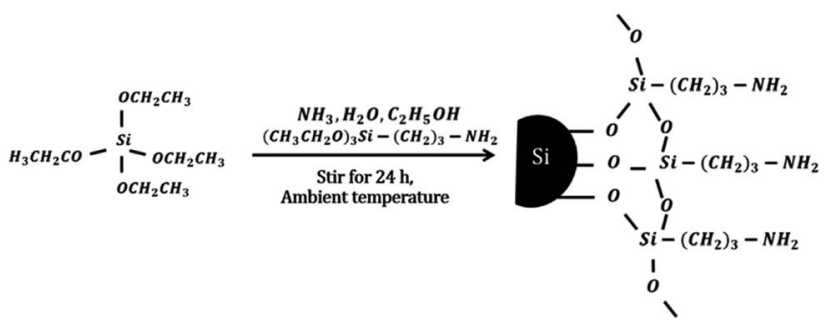

\subsection{Rubber foam preparation}

Table 1 shows the formulation of the NR compound. First, the K-oleate dispersion was added to the NR latex and beaten for 10 min by either CM or OS to make a foam as shown in Fig. 1. The rotation speeds of CM and OS were at 100 and 500 revolutions per minute (rpm). Then the sulfur, ZDEC, ZMBT, Wingstay L, DPG, ZnO and SSF dispersions were slowly added and continuously beaten for $2 \mathrm{~min}$. The total NR compound volume after mixing by CM increased five-fold, while that by OS increased two-fold compared to the initial volume. The rubber compound was then poured into a glass mold and cured in a hot-air oven at $100{ }^{\circ} \mathrm{C}$ for $2 \mathrm{~h}$ to cure, washed with water to eliminate the unreacted chemicals and dried in a hot-air oven at $70{ }^{\circ} \mathrm{C}$ for $20 \mathrm{~h}$. For preparation of the filled CM composite foam, USi or MSi particles were initially mixed with the K-oleate, and thereafter the same procedure was performed as above to prepare the CM-USi or CM-MSi composites, respectively.

\subsection{Characterization}

The functional groups of the MSi particles were characterized by FT-IR (PerkinElmer, Shelton, USA) analysis. Each sample was prepared in a $\mathrm{KBr}$ disk under high pressure, and the FT-IR

Table 1 Formulation for the NR latex foam compound ${ }^{g}$

\begin{tabular}{|c|c|c|c|c|}
\hline Ingredient & $\begin{array}{l}\mathrm{CM}^{a} \\
(\mathrm{phr})^{b}\end{array}$ & $\begin{array}{l}\mathrm{OS}^{c} \\
(\mathrm{phr})\end{array}$ & $\begin{array}{l}\text { CM-USi } \\
\text { (phr) }\end{array}$ & $\begin{array}{l}\text { CM-MSi } \\
\text { (phr) }\end{array}$ \\
\hline $60 \%$ DRC NR latex ${ }^{d}$ & 100 & 100 & 100 & 100 \\
\hline $10 \%$ K-oleate dispersion & 15 & 15 & 15 & 15 \\
\hline $50 \%$ sulfur dispersion & 4 & 4 & 4 & 4 \\
\hline 50\% ZDEC dispersion & 2 & 2 & 2 & 2 \\
\hline 50\% ZMBT dispersion & 2 & 2 & 2 & 2 \\
\hline $50 \%$ Wingstay L dispersion & 2 & 2 & 2 & 2 \\
\hline 33\% DPG dispersion & 2 & 2 & 2 & 2 \\
\hline 50\% ZnO dispersion & 10 & 10 & 10 & 10 \\
\hline $12.5 \%$ SSF dispersion & 8 & 8 & 8 & 8 \\
\hline $\mathrm{USi}^{e}$ & - & - & 5 & - \\
\hline $\mathrm{MSi}^{f}$ & - & - & - & 5 \\
\hline
\end{tabular}

${ }^{a}$ NR latex foam prepared by cake mixer. ${ }^{b}$ Parts by weight per hundred parts of rubber. ${ }^{c}$ NR latex foam prepared by overhead stirrer. ${ }^{d}$ All chemicals are calculated based on $60 \%$ dry rubber content (DRC) of the NR latex. ${ }^{e}$ Unmodified silica particles. ${ }^{f}$ Modified silica particles by (3-aminopropyl)triethoxysilane (APTES). ${ }^{g}$ Conditions: the rubber compound was mixed at ambient temperature and cured for $2 \mathrm{~h}$ at $100{ }^{\circ} \mathrm{C}$. 


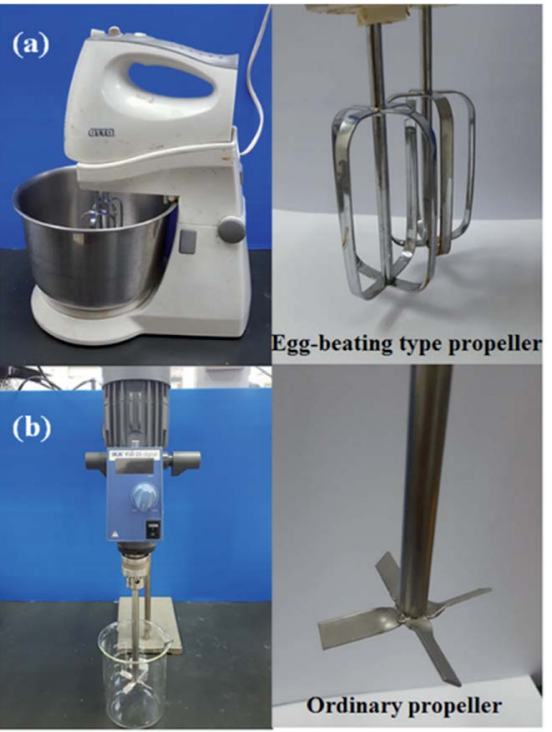

Fig. 1 The feature of the (a) cake mixer with egg-beating type propeller and (b) overhead stirrer with ordinary propeller.

spectra were recorded from 4000 to $400 \mathrm{~cm}^{-1}$ at a resolution of $4 \mathrm{~cm}^{-1}$. The carbon, hydrogen, and nitrogen contents on the silica surface were examined by a PerkinElmer (PE-2400, Waltham, USA) CHNS/O elemental analyzer. The morphology of the MSi particles was examined by TEM (FEI TECNAI T20, Eindhoven, Netherland), operated at $120 \mathrm{kV}$. The samples were suspended in EtOH and then dropped onto a copper grid to dry at room temperature. The morphology of each NR latex foam was also studied by SEM (JEOL, JSM-6480LV, Tokyo, Japan) at an accelerating voltage of $15 \mathrm{kV}$. The samples were placed on a stub and coated with gold before measurement.

\section{5. $\mathrm{CO}_{2}$ adsorption-desorption performance}

Fig. 2 shows a schematic representation of the experimental apparatus used to determine the $\mathrm{CO}_{2}$ adsorption. In order to eliminate any physisorbed or chemisorbed $\mathrm{CO}_{2}$ in the sorbent materials, the dried sorbent material $(2.0 \mathrm{~g})$ was treated under

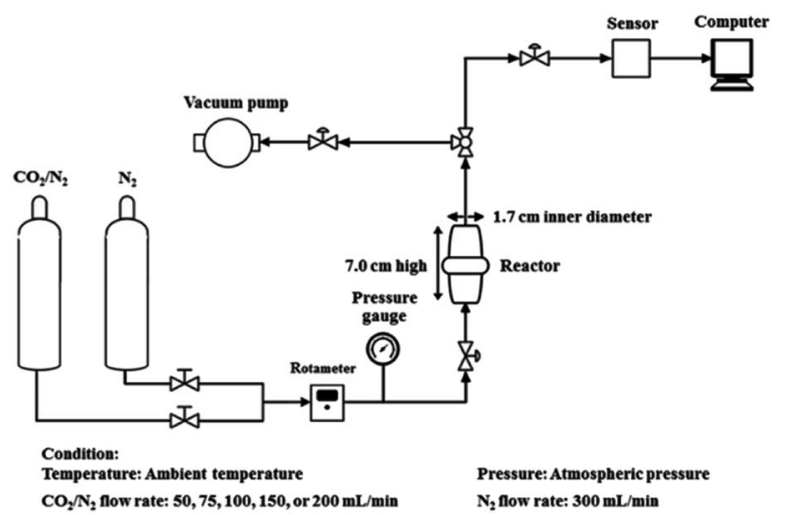

Fig. 2 Schematic representation of the $\mathrm{CO}_{2}$ adsorption apparatus used in this study. vacuum at $60{ }^{\circ} \mathrm{C}$, packed into a stainless-steel reactor $(1.7 \mathrm{~cm}$ inner-diameter and $7.0 \mathrm{~cm}$-height), and treated under vacuum followed by a $\mathrm{N}_{2}$ flow ( $300 \mathrm{~mL} \mathrm{~min}^{-1}$ ). The gas flow was then switched to a mixed gas $\left(12.88: 87.12(\mathrm{v} / \mathrm{v}) \mathrm{CO}_{2}: \mathrm{N}_{2}\right)$ at various flow rates $\left(75,100,150\right.$ and $\left.200 \mathrm{~mL} \mathrm{~min}^{-1}\right)$. The $\mathrm{CO}_{2}$ adsorption capacity was calculated based on the difference between the total inlet and outlet $\mathrm{CO}_{2}$ amounts. The mean residence time was determined by flowing the mixed gas $(12.88: 87.12(\mathrm{v} / \mathrm{v})$ $\mathrm{CO}_{2}: \mathrm{N}_{2}$ ) through the stainless steel reactor without any sorbent. Therefore, the $\mathrm{CO}_{2}$ adsorption capacity was directly proportional to the area difference above the $\mathrm{CO}_{2}$ breakthrough curves. The adsorption process was operated at atmospheric pressure and ambient temperature. The released $\mathrm{CO}_{2}$ from the reactor was measured via an online sensor (K33 BLG sensor, Florida, USA).

The regeneration of the sorbent material was performed by a combination of vacuum and temperature swing adsorption processes in the stainless-steel reactor. The sorbent material was heated at $60{ }^{\circ} \mathrm{C}$ under a reduced pressure condition with

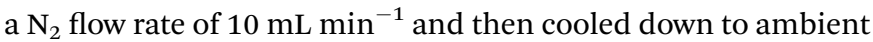
temperature. After that, the sorbent material was subjected to a repeat $\mathrm{CO}_{2}$ adsorption process. This $\mathrm{CO}_{2}$ adsorption-desorption was continued for 12 cycles in this study.

\section{Results and discussion}

\subsection{Characterization of the MSi particles}

Representative FT-IR spectra of the USi and MSi particles are shown in Fig. 3. The $\mathrm{O}-\mathrm{OH}$ stretching of moisture and $\mathrm{SiO}-\mathrm{H}$ stretching of USi appeared at $3434 \mathrm{~cm}^{-1} \cdot{ }^{37-39}$ Furthermore, the absorption band corresponding to the deformation vibrations of the adsorbed water molecules appeared at $1630 \mathrm{~cm}^{-1}$, while the $\mathrm{Si}-\mathrm{O}$ in-plane stretching vibrations of the silanol $\mathrm{Si}-\mathrm{OH}$ group appeared at $948 \mathrm{~cm}^{-1} \cdot{ }^{37-39}$ Additionally, the characteristic peaks of the Si-O-Si asymmetric, symmetric, and bending modes of silica were shown at 1107,802 , and $474 \mathrm{~cm}^{-1}$, respectively. ${ }^{40}$

After the modification of the silica surface with APTES to yield the MSi particles, additional absorption bands were observed at $2945 \mathrm{~cm}^{-1}$ and $1480 \mathrm{~cm}^{-1}$, which represent the $\mathrm{C}-\mathrm{H}$

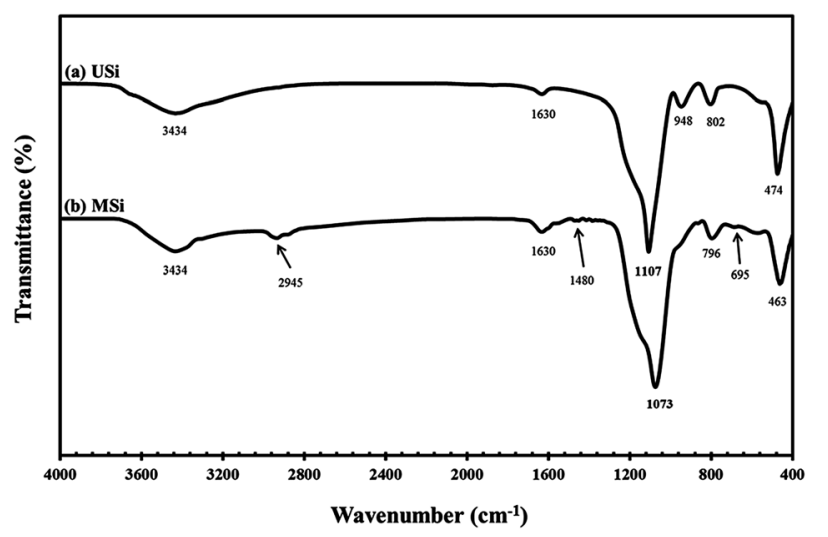

Fig. 3 Representative FT-IR spectra of the (a) USi and (b) MSi particles. 
Table 2 The elemental analysis (by weight) and particle size of the unmodified (USi) and modified (MSi) silica particles

\begin{tabular}{lllll}
\hline & \multicolumn{2}{l}{ Elemental analysis ${ }^{a}(\mathrm{wt} \%)$} & \\
\cline { 2 - 4 } Sample & $\mathrm{C}$ & $\mathrm{H}$ & $\mathrm{N}$ & \\
\hline USi & 0.00 & 1.09 & 0.00 & $176 \pm 23$ \\
MSi & 10.88 & 3.28 & 3.98 & $208 \pm 36$
\end{tabular}

${ }^{a}$ By CHN analysis. ${ }^{b}$ By TEM analysis.

stretching vibration ${ }^{41}$ and $\mathrm{NH}_{2}$ deformation of hydrogenbonded amine groups, respectively. ${ }^{42}$ The band at $695 \mathrm{~cm}^{-1}$ was attributed to the $\mathrm{Si}-\mathrm{C}$ stretching vibration of the methyl group bonded to a silicon atom. ${ }^{43}$ However, the $-\mathrm{NH}_{2}$ groups at $3300-3800 \mathrm{~cm}^{-1}$ were not evident in the MSi particles due to the interference of moisture or water molecules. ${ }^{44}$ Table 2 shows the elemental analysis of the USi and MSi particles, where the USi particles showed a hydrogen content of only $1.09 \mathrm{wt} \%$, which came from the water adsorbed on the USi particles' surface. After modification, the $\mathrm{C}, \mathrm{H}, \mathrm{N}$ contents were increased,
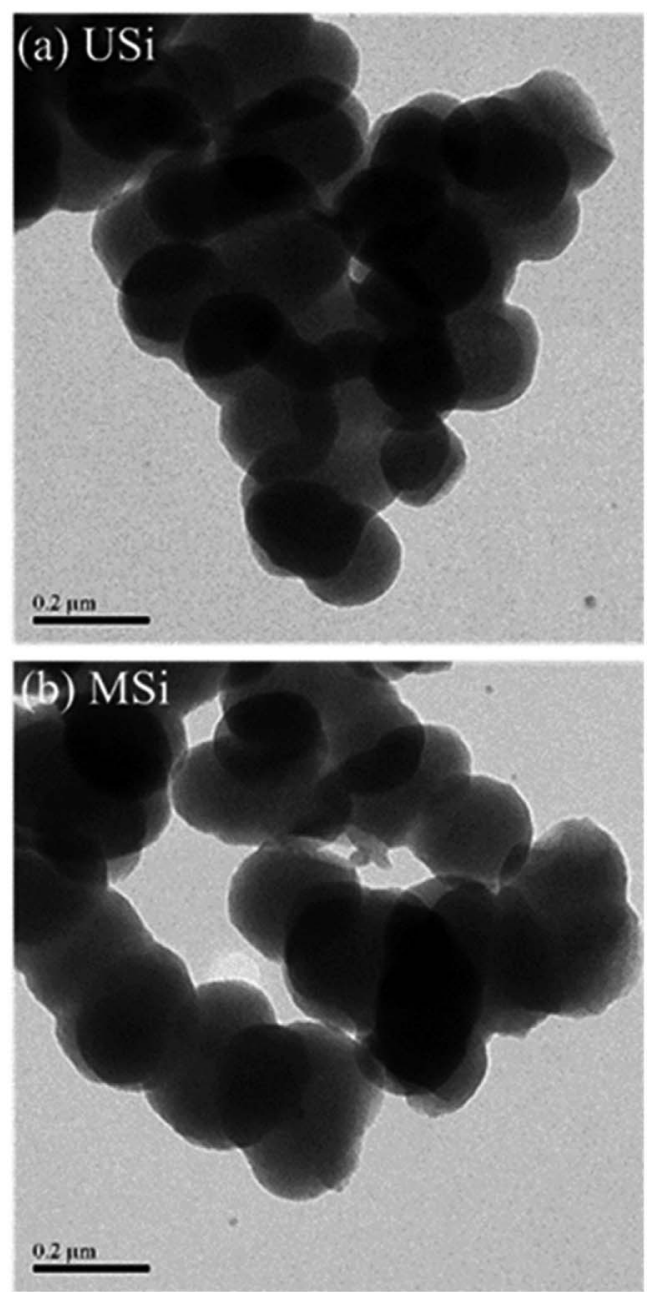

Fig. 4 Representative TEM micrographs (19000× magnification; scale bar $=0.2 \mu \mathrm{m}$ ) of the (a) USi and (b) MSi particles. supporting that the modification of the silica particles by APTES was completely achieved.

Fig. 4 shows the morphology of the USi and MSi particles as observed by TEM. The USi and MSi particles were of a uniform spherical shape, with average anhydrous particle sizes of about $176 \pm 23 \mathrm{~nm}$ and $208 \pm 36 \mathrm{~nm}$, respectively. The fact that the size of the MSi particles was larger (ca. 1.18-fold) than that of the USi particles was due to the organic group of the APTES modifier covering the silica surface.

\subsection{Characterization of the different NR (OS and CM) foams}

The NR latex foams were prepared by OS and CM in order to evaluate the effect of the NR latex foam morphology on the $\mathrm{CO}_{2}$ adsorption performance. The morphologies of the OS and CM rubber foams are shown in Fig. 5. Both types of the NR latex foam showed a spherical-shaped open cell structure, but the cell size of the OS foam $(78 \pm 29 \mu \mathrm{m})$ was about 4.3 -fold smaller than that of the CM foam $(338 \pm 33 \mu \mathrm{m})$. It is interesting to note that the number of pores per cell in the CM foam was more than that in the OS foam. Moreover, the cells in the OS foam were generally interconnected with each other, which may have decreased the available surface area of the sorbent material for $\mathrm{CO}_{2}$ adsorption. In contrast, the cells of the CM foam showed a well-defined cell wall ${ }^{45}$ and a large capacity for potential $\mathrm{CO}_{2}$ capture. The morphology of the CM foam after filling with USi or MSi particles was similar to that of the neat CM foam (Fig. 5(c) and (d)).

\section{3. $\mathrm{CO}_{2}$ adsorption performance}

In order to test the $\mathrm{CO}_{2}$ adsorption performance of the different prepared NR latex foams, they were evaluated in a mixed gas flow in a stainless-steel reactor at ambient temperature and pressure. The effects of the mixed gas flow rate on the $\mathrm{CO}_{2}$ adsorption capacity of the different NR latex foams were evaluated. The $\mathrm{CO}_{2}$ adsorption capacity of the OS and CM foams increased when the mixed gas flow rate was increased from 75 to $100 \mathrm{~mL} \mathrm{~min}^{-1}$ (Fig. 6), which was due to the increased driving force of the mixed gas through the NR latex foam. However, the $\mathrm{CO}_{2}$ adsorption capacity of both types of the NR latex foam gradually decreased as the mixed gas flow rate increased above $100 \mathrm{~mL} \mathrm{~min}^{-1}$. This may be because at a higher mixed gas flow rate a shorter residence time was obtained. ${ }^{8}$ Interestingly, the $\mathrm{CO}_{2}$ adsorption capacity of the CM foam was higher than that of the OS foam at all mixed gas flow rates, which was presumably due to the higher number of pores per cell able to capture more $\mathrm{CO}_{2}$, whereas the OS foam had a smaller cell size with a lower number of pores per cell (Fig. 7). The only interaction between $\mathrm{CO}_{2}$ and the different NR latex foams was physisorption. Accordingly, in this study, the CM foam was chosen to evaluate the effect of the addition of USi or MSi fillers in an attempt to improve the $\mathrm{CO}_{2}$ adsorption capacity.

Fig. 8 shows the breakthrough curves of the CM-USi and CMMSi foams. A breakthrough curve shows the relationship between the ratios of the $\mathrm{CO}_{2}$ concentration at the outlet to the initial $\mathrm{CO}_{2}$ concentration at the inlet of the reactor $\left(C / C_{0}\right)$ over time. Initially, no $\mathrm{CO}_{2}$ was detected in the outlet gas because the 

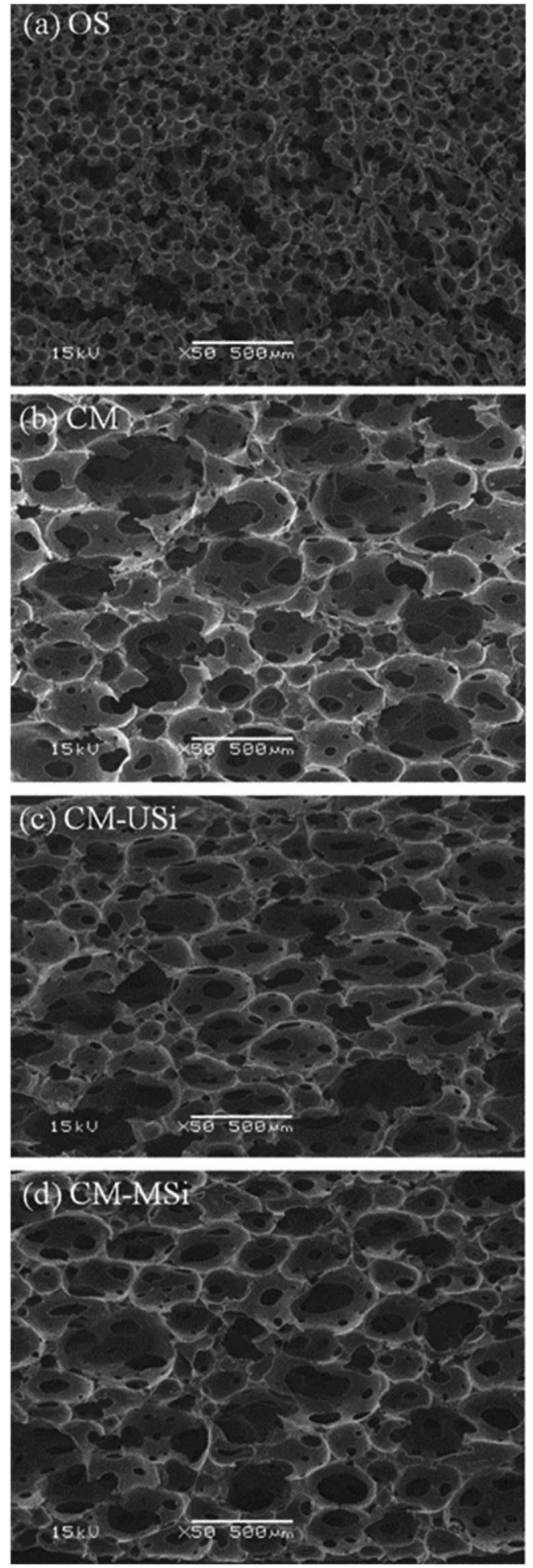

Fig. 5 Representative SEM micrographs (50 000× magnification; scale bar $=500 \mu \mathrm{m}$ ) of the NR latex foam formed by (a) OS and (b) CM, and of the CM foam filled with either (c) USi or (d) MSi particles by different techniques.

inlet $\mathrm{CO}_{2}$ was completely adsorbed on the respective NR latex foam. The breakthrough time (the time at which the effluent $\mathrm{CO}_{2}$ concentration reaches a $10 \%$ allowable breakthrough concentration $^{46}$ ) increased when the CM foam was filled with

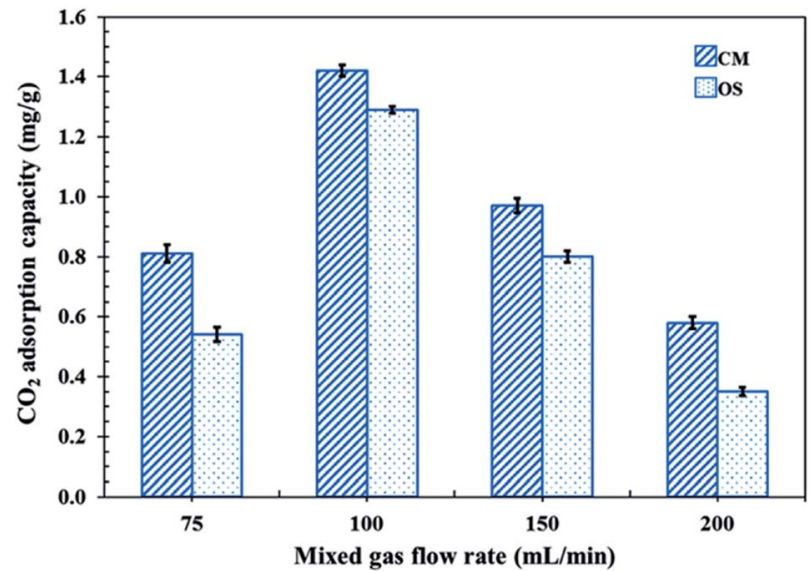

Fig. $6 \mathrm{CO}_{2}$ adsorption capacity of the $\mathrm{CM}$ and $\mathrm{OS}$ foams at different mixed gas flow rates $\left(50,75,100,150\right.$ and $200 \mathrm{~mL} \mathrm{~min}{ }^{-1}$ ) under ambient temperature and pressure.

either USi or MSi particles, and was ranked in the order CM-MSi $>$ CM-USi > CM. Thereafter, the curves slowly and continuously increased, since the $\mathrm{CO}_{2}$ adsorption performance slowly decreased, resulting in an increasing $\mathrm{CO}_{2}$ concentration in the outlet gas. Finally, the curves became constant at 1.0 (outlet $\mathrm{CO}_{2}$ concentration equals that of the inlet) because the adsorbents were saturated with $\mathrm{CO}_{2}$. The total $\mathrm{CO}_{2}$ adsorption capacity was (a) OS

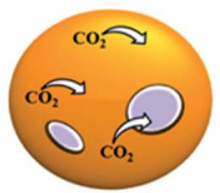

(c) CM-USi

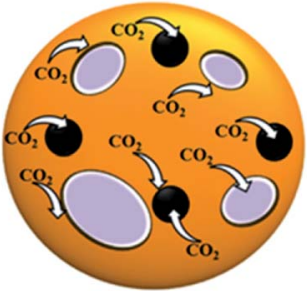

(b) $\mathrm{CM}$

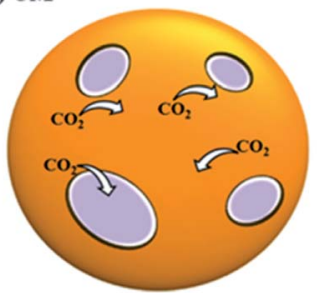

(d) CM-MSi

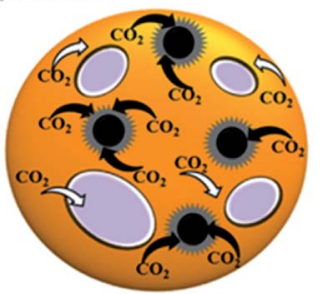

(e)

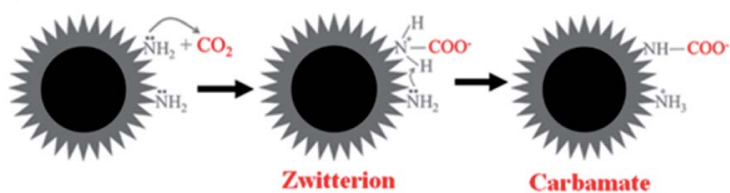

Foam cell Pore Unmodified silica

L Physisorption Chemisorption

Fig. 7 Proposed mechanisms of $\mathrm{CO}_{2}$ adsorption for the (a) $\mathrm{OS}$, (b) $\mathrm{CM}$, (c) CM-USi and (d) CM-MSi foams, and (e) chemisorption between $\mathrm{CO}_{2}$ and modified silica in CM-MSi foam. 


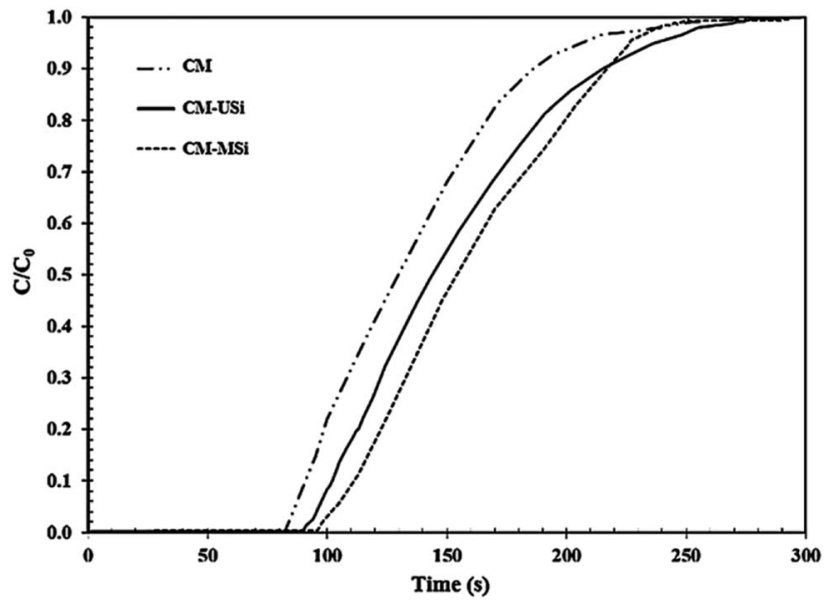

Fig. 8 Breakthrough curves of the NR latex foam, and the rubber composite of the CM foam filled with either USi (CM-USi) or MSi (CMMSi) particles at a mixed gas flow rate of $100 \mathrm{~mL} \mathrm{~min}^{-1}$ under ambient temperature and pressure.

calculated from the area above the breakthrough curves and is shown in Table 3. The $\mathrm{CO}_{2}$ adsorption capacity of the CM-MSi foam was clearly the highest followed by that of the CM-USi foam and these were 2.87 and 2.6-fold higher, respectively, than that of CM foam. These results indicated that the high adsorption capacity of the CM-MSi foam was due not only to physisorption between $\mathrm{CO}_{2}$ and the $\mathrm{CM}$ foam, but also to chemisorption between $\mathrm{CO}_{2}$ and the amine groups to form a carbamate on the surface of the MSi particles, ${ }^{47,48}$ whereas the only interaction between $\mathrm{CO}_{2}$ and the CM-USi foam was physisorption (Fig. 7).

Fig. 9 shows the $\mathrm{CO}_{2}$ adsorption-desorption of CM, CM-USi and CM-MSi foams over 12 successive cycles. The $\mathrm{CO}_{2}$ adsorption capacity of the CM foam dropped $27.9 \%$ after five cycles of regeneration, while the $\mathrm{CO}_{2}$ adsorption capacity of CM-USi and CM-MSi foams decreased by 11.9 and $12.4 \%$ after 10 and 9 cycles of regeneration, respectively. This suggested that CM-USi and CM-MSi foams exhibited a better regenerative ability than the CM foam. Accordingly, the presence of USi or MSi particles gave a higher stability to reuse the sorbent

Table $3 \mathrm{CO}_{2}$ adsorption capacity of the different NR latex foams (OS and $(M)$ and the CM foam filled with either USi or MSi particles, at a mixed gas flow rate of $100 \mathrm{~mL} \mathrm{~min}{ }^{-1}$ under ambient temperature and pressure

\begin{tabular}{ll}
\hline Sample & $\mathrm{CO}_{2}$ adsorption capacity $^{a}\left(\mathrm{mg} \mathrm{g}^{-1}\right)$ \\
\hline $\mathrm{OS}^{b}$ & $1.29 \pm 0.1$ \\
$\mathrm{CM}^{c}$ & $1.42 \pm 0.3$ \\
$\mathrm{CM}^{c} \mathrm{USi}^{d}$ & $3.69 \pm 0.2$ \\
$\mathrm{CM}^{\mathrm{MSi}}{ }^{e}$ & $4.08 \pm 0.2$
\end{tabular}

${ }^{a} \mathrm{mg}$ of $\mathrm{CO}_{2}$ per $\mathrm{g}$ of adsorbent. ${ }^{b}$ NR latex foam prepared by overhead stirrer. ${ }^{c}$ NR latex foam prepared by cake mixer. ${ }^{d}$ NR latex foam prepared by cake mixer filled with unmodified silica particles. ${ }^{e}$ NR latex foam prepared by cake mixer filled with silica particles modified by (3-aminopropyl)triethoxysilane (APTES).
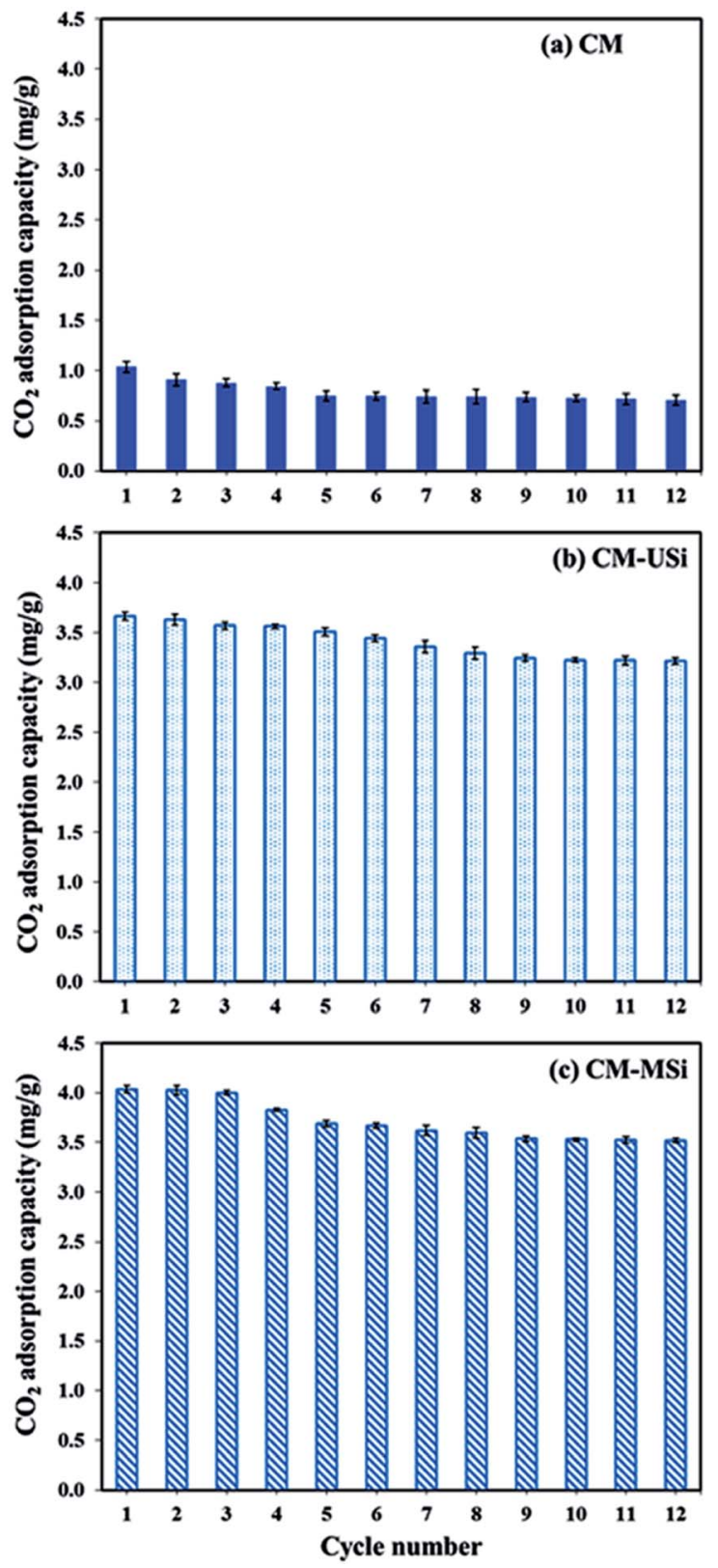

Fig. 9 The $\mathrm{CO}_{2}$ uptake of (a) CM, (b) CM-USi and (c) CM-MSi foams over 12 adsorption-desorption cycles; adsorption: a mixed gas flow rate of $100 \mathrm{~mL} \mathrm{~min}{ }^{-1}$ under ambient temperature and pressure; desorption: $60^{\circ} \mathrm{C}$ under vacuum for $20 \mathrm{~min}$.

materials compared to the CM foam. However, when comparing the overall regeneration performance of all the sorbents, the $\mathrm{CO}_{2}$ adsorption capacity dropped to constant values without a further decrease in the $\mathrm{CO}_{2}$ adsorption capacity. This shows the advantage when using these sorbent materials in a real operation.

Table 4 shows the comparison of $\mathrm{CO}_{2}$ adsorption capacities of various sorbent materials. Each sorbent material showed the different $\mathrm{CO}_{2}$ adsorption capacities due to the different surface properties, nature of sorbent material (porous powder, film, or foam) or testing condition. When comparing the capture 
Table 4 Comparison of $\mathrm{CO}_{2}$ adsorption capacities of various sorbent materials

\begin{tabular}{|c|c|c|c|c|}
\hline Sorbent materials & Temperature $\left({ }^{\circ} \mathrm{C}\right)$ & Pressure (bar) & $\mathrm{CO}_{2}$ adsorption capacity $\left(\mathrm{mg} \mathrm{g}^{-1}\right)$ & Ref \\
\hline Polyamide-6 & 25 & 1.0 & 1.00 & 49 \\
\hline PA/CNT-PEI-100 ${ }^{a}$ & 25 & 1.0 & 10.0 & 49 \\
\hline $\mathrm{S} 12^{b}$ & 40 & 1.0 & 9.24 & 51 \\
\hline $\mathrm{N}-\mathrm{OMPs}{ }^{c}$ & 25 & 0.15 & 29.5 & 52 \\
\hline $\mathrm{CM}-\mathrm{MSi}^{d}$ & Ambient & 1.0 & 4.08 & Thi \\
\hline
\end{tabular}

${ }^{a}$ Polyamide-6/carbon nanotube composite impregnated with polyethyleneimine (100 wt\%). ${ }^{b}$ Nano silica particles with the particle size of $12 \mathrm{~nm}$. ${ }^{c}$ Nitrogen-doped ordered mesoporous polymers. ${ }^{d}$ NR latex foam prepared by cake mixer filled with silica particles modified by (3-aminopropyl) triethoxysilane (APTES).

capacity of various kinds of sorbent material, CM-MSi can be a candidate for using as a solid sorbent because the adsorbent can be prepared as the green and non-toxic adsorbent material. In addition, this material still can modify to further increase the $\mathrm{CO}_{2}$ capture capacity.

\section{Conclusions}

In this study, NR-based composite materials were designed and developed for $\mathrm{CO}_{2}$ capture at ambient temperature and pressure. Based on a SEM analysis, the CM foam showed a larger cell size with many pores per cell, resulting in a higher $\mathrm{CO}_{2}$ adsorption capacity compared to the OS foam. The optimum condition to obtain the highest $\mathrm{CO}_{2}$ adsorption capacity of the CM foam (1.42 $\mathrm{mg} \mathrm{g}^{-1}$ ) was the use of the mixed gas $\left(12.88: 87.12(\mathrm{v} / \mathrm{v}) \mathrm{CO}_{2}: \mathrm{N}_{2}\right)$ at a flow rate of $100 \mathrm{~mL} \mathrm{~min}^{-1}$ at ambient temperature and pressure. To further improve the $\mathrm{CO}_{2}$ adsorption performance of the CM foam, USi or MSi particles were filled in the rubbery matrix, whereupon the $\mathrm{CO}_{2}$ adsorption capacity increased by more than 2.6 and 2.87 -fold, respectively, compared to the unfilled CM foam. The high adsorption capacity of CM-MSi was due to the presence of both physical and chemical adsorption, while the interaction of $\mathrm{CO}_{2}$ and CM-USi represented only physical adsorption. Accordingly, the CM-MSi composite foam can be used as a solid sorbent or designed for $\mathrm{CO}_{2}$ capture in high $\mathrm{CO}_{2}$ release areas, such as gas stations, car parks, traffic jams or hospitals.

\section{Conflicts of interest}

The authors have declared no conflict of interest.

\section{Acknowledgements}

The authors gratefully acknowledge the funding support from the Thailand Research Fund (Grant No. RSA6180030) and Malaysia-Thailand Joint Authority (MTJA), Research Cess Fund.

\section{References}

1 D. Leesona, N. M. Dowell, N. Shaha, C. Petit and P. S. Fennell, Int. J. Greenhouse Gas Control, 2017, 61, 71-84.
2 C. H. Yu, C. H. Huang and C. S. Tan, Aerosol Air Qual. Res., 2012, 12, 745-769.

3 D. M. D'Alessandro, B. Smit and J. R. Long, Angew. Chem., Int. Ed., 2010, 49, 6058-6082.

4 J. De Rivaa, J. Suarez-Reyes, D. Morenoa, I. Díaz, V. Ferroa and J. Palomar, Int. J. Greenhouse Gas Control, 2017, 61, 6170.

5 H. Kim, H. Shi and J. Y. Lee, Int. J. Greenhouse Gas Control, 2016, 45, 181-188.

6 L. Hauchhum and P. Mahanta, Int. J. Energy Environ. Eng., 2014, 5, 349-356.

7 K. M. Lee, Y. H. Lim, C. J. Park and Y. M. Jo, Ind. Eng. Chem. Res., 2012, 51, 1355-1363.

8 X. Wang, L. Chen and Q. Guo, Chem. Eng. J., 2015, 260, 573581.

9 C. F. Song, Y. Kitamura, S. H. Li and K. Ogasawara, Int. J. Greenhouse Gas Control, 2012, 7, 107-114.

10 B. Belaissaoui, Y. L. Moullec, D. Willson and E. Favre, J. Membr. Sci., 2012, 415-416, 424-434.

11 X. Gao, X. Zou, H. Ma, S. Meng and G. Zhu, Adv. Mater., 2014, 26, 3644-3648.

12 R. Wang, H. Y. Zhang, P. H. M. Feron and D. T. Liang, Sep. Purif. Technol., 2005, 46, 33-40.

13 G. Zhao, X. Huang, X. Wang and X. Wang, J. Mater. Chem. A, 2017, 5, 21625-21649.

14 G. Zhao, W. Zhou, Y. Sun, X. Wang, H. Liu, X. Meng, K. Chang and J. Ye, Appl. Catal., B, 2018, 226, 252-257.

15 E. Abbasi, A. Hassanzadeh, S. Zarghami, H. Arastoopour and J. Abbasian, Fuel, 2014, 137, 260-268.

16 C. Wang, B. Dou, Y. Song, H. Chen, Y. Xu and B. Xie, Ind. Eng. Chem. Res., 2014, 53, 12744-12752.

17 C. Gunathilake and M. Jaroniec, J. Mater. Chem. A, 2016, 4, 10914-10924.

18 T. A. Saleh, Advanced Nanomaterials for Water Engineering, Treatment, and Hydraulics, IGI Global, 2017, ISBN13: 9781522521365.

19 T. A. Saleh and V. K. Gupta, Nanomaterial and Polymer Membranes: Synthesis, Characterization, and Applications, Elsevier, 2016, ISBN: 978-0128047033.

20 C. F. Martín, E. Stöckel, R. Clowes, D. J. Adams, A. I. Cooper, J. J. Pis, F. Rubiera and C. Pevida, J. Mater. Chem., 2011, 21, 5475-5483. 
21 Z. Xiang and D. Cao, J. Mater. Chem. A, 2013, 2, 2691-2718. 22 X. Zou and G. Zhu, Adv. Mater., 2018, 30, 1700750.

23 N. B. McKeown and P. M. Budd, Chem. Soc. Rev., 2006, 35, 675-683.

24 T. A. Saleh, A. Sari and M. Tuzen, J. Environ. Chem. Eng., 2017, 5, 1079-1088.

25 T. A. Saleh and S. Ali, J. Environ. Chem. Eng., 2018, 6, 53615368.

26 K. C. Baranwal and H. L. Stephens, Basic Elastomer Technology, Rubber Division, Akron, 1st edn, 2001.

27 J. Johns and V. Rao, Int. J. Polym. Mater. Polym. Biomater., 2011, 60, 766-775.

28 X. Zhang, Z. Lu, D. Tian, H. Li and C. Lu, Appl. Polym. Sci., 2013, 127, 4006-4014.

29 S. Tomyangkul, P. Pongmuksuwan, W. Harnnarongchai and K. Chaochanchaikul, J. Reinf. Plast. Compos., 2016, 35, 672681.

30 S. A. Riyajan and P. Keawittarit, Polym. Int., 2016, 65, 491502.

31 N. Rattanasoma, T. Saowapark and C. Deeprasertkul, Polym. Test., 2007, 26, 369-377.

32 S. Prasertsri and N. Rattanasom, Polym. Test., 2012, 31, 593605.

33 A. Tunlert, P. Prasassarakich and S. Poompradub, Mater. Chem. Phys., 2016, 173, 78-88.

34 Y. Belmabkhout, R. Serna-Guerrero and A. Sayari, Chem. Eng. Sci., 2009, 64, 3721-3728.

35 R. S. Franchi, P. J. E. Harlick and A. Sayari, Ind. Eng. Chem. Res., 2005, 44, 8007-8013.

36 D. G. P. M. Perera, T. O. Kumanayaka and S. Walpalage, Int. J. Sci. Res., 2015, 5, 1-5.
37 R. A. Oweini and H. E. Rassy, J. Mol. Struct., 2009, 919, 140145.

38 T. A. Saleh, Desalin. Water Treat., 2015, 57, 10730-10744.

39 T. A. Saleh, Environ. Sci. Pollut. Res., 2015, 22, 16721-16731.

40 N. D. Hegde and A. V. Rao, Appl. Surf. Sci., 2006, 253, 15661572.

41 A. M. Donia, A. A. Atia, A. M. Daher, O. A. Desouky and E. A. Elshehy, Int. J. Miner. Process., 2011, 101, 81-88.

42 S. C. Hsu, C. Lu, F. Su, W. Zeng and W. Chen, Chem. Eng. Sci., 2010, 65, 1354-1361.

43 G. Hernández and R. Rodríguez, J. Non-Cryst. Solids, 1999, 246, 209-215.

44 T. Theppradit, P. Prasassarakich and S. Poompradub, Mater. Chem. Phys., 2014, 148, 940-948.

45 H. M. Lim and M. Y. Amir-Hashim, J. Rubber Res., 2011, 14, 41-50.

46 F. Su, C. Lu, S. C. Kuo and W. Zeng, Energy Fuels, 2010, 24, 1441-1448.

47 N. N. Linneen, R. Pfeffer and Y. S. Lin, Chem. Eng. J., 2014, 254, 190-197.

48 M. Yao, Y. Dong, X. Feng, X. Hu, A. Jia, G. Xie, G. Hu, J. Lu, M. Luo and M. Fan, Fuel, 2014, 123, 66-72.

49 G. Zainab, N. Iqbal, A. A. Babar, C. Huang, X. Wang, J. Yu and B. Ding, Compos. Commun., 2017, 6, 41-47.

50 M. R. Mello, D. Phanon, G. Q. Silveira, P. L. Llewellyn and C. M. Ronconi, Microporous Mesoporous Mater., 2011, 143, 174-179.

51 I. H. Arelloano, J. Huang and P. Pendleton, RSC Adv., 2015, 5, 65074-65083.

52 F. Liu, K. Huang, Q. Wu and S. Dai, Adv. Mater., 2017, 29(18), 1700445. 